\title{
CONTINGENCY AND COMPARISON: RECALLING BEN ANDERSON
}

\section{Vicente L. Rafael}

I first met Benedict Anderson in 1979 when I began my graduate work at Cornell. He invited me to his home for dinner, some ten miles from Ithaca in a town improbably called Freeville-then the location of a juvenile detention facility called George Junior Republic (now called the William George Agency for Children's Services) that was the model for the Iwahig Penal Colony in the Philippines. Appropriately enough for Ben-a connoisseur of irony-his home used to be the warden's, who had to leave town hurriedly because of some scandal. ${ }^{1}$

This anecdote says something about the Cornell of Ben Anderson, the Cornell that I knew. It was a fertile field for inducing two of the most characteristic aspects of his work: contingency and comparison. Indeed, one grew out of the other. It is this relationship that I would like to talk about, recalling how they figured in Ben's life and works.

As I was beginning my dissertation in 1983, in the wake of Ninoy Aquino's assassination, Ben had just published Imagined Communities. ${ }^{2}$ His office was directly below mine in an old house on West Avenue that served as the site for Cornell's Modern Indonesia Project, more commonly known by its denizens as "102 West," or

Vicente L. Rafael is Professor, History Department, University of Washington, Seattle.

${ }^{1}$ For a history of the Iwahig Penal colony modeled after the George Junior Republic in Freeville, New York, see Michael Salman, "The Prison that Makes Men Free': The Iwahig Penal Colony and the Simulacra of the American State in the Philippines," in Colonial Crucible: Empire in the Making of the Modern American State, ed. Alfred W. McCoy and Francisco A. Scarano (Madison: University of Wisconsin Press, 2009), 116-29. The information on Ben's house comes from a personal e-mail correspondence, 2010.

${ }^{2}$ Benedict Anderson, Imagined Communities: Reflections on the Origin and Spread of Nationalism (London: Verso, 1983). 
just "102." It was a former fraternity house whose members had been kicked off campus for some transgression, so we were essentially on frat row. The chairs and tables were scarred and stained from cigarettes and coffee cups, the doors were cracked, the stairs creaked, and parts of the balustrade at times came off in your hands. During nice weather, frat boys sunbathed on nearby roofs, waged beer-balloon wars, and played very loud rock-and-roll music around us. Faculty, students, and visiting professors worked in various offices at 102 West, often late into the night, and met for evening seminars and weekly brown bags that featured speakers ranging from diplomats to foreign scholars. The basement was full of boxes of file folders, which I always thought were Ben's research notes, turning the place into a veritable firetrap.

102 West, in short, was an ideal place to work. Its ramshackle quality lent to it the feel of a refugee camp: physically precarious, resistant to domestication, but also ripe with insurgent possibilities. At 102, unexpected connections grew into friendships that led people to paths other than what they thought they had embarked on. Its informal atmosphere allowed for explorations of all sorts that deconstructed and deviated from the disciplinary formations that fixed and fixated many of us. Firmly but gently, Ben-sitting in his office, presiding over seminars, asking questions that always surprised and disoriented us - served as the tutelary spirit of $102 .{ }^{3}$

One of the things that drew me, and doubtless many others, to Ben was precisely his style of thinking. He readily admitted that he was not a theorist and not really a political scientist. He shied away from fashionable labels such as post-structuralist or post-colonialist, and the classicist in him, with its love for lexical precision and rhetorical economy, abhorred the theoretical hyperventilation and logorrhea that often plagues the American academy. More likely, he would have preferred to be called a historian and a novelist, both of which are closely related to one another. As a historian-novelist, Ben was drawn to the contingent constellations of people and events, reveling in their surprising and unexpected juxtapositions. All of these generated not only alternative and parallel versions relative to what had happened; they also opened up doors into worlds that could have happened. In other words, for Ben, thinking entailed recuperating those events and imaginings that had to be repressed in the making of reigning realities.

We can see the critical role of contingency in his various autobiographies. For example, in his introduction to Language and Power: Exploring Political Cultures in Indonesia, ${ }^{4}$ Ben relates how he came to be involved with Southeast Asian studies. ${ }^{5}$ It started with a blow to his face. While studying classical languages at Cambridge in 1956, he found himself wandering into a political demonstration held by a small group

${ }^{3} 102$ West Avenue was long ago demolished to make room for a parking lot. There is not even a historical plaque that commemorates its existence. In the early $1990 \mathrm{~s}$, the Southeast Asia Program offices were transferred to a stately Tudor mansion about half a mile away on Stewart Avenue, a building that is more formal than 102. The move was funded by Japanese donors. When I visited Cornell in 2007, I noticed a large photograph of 102 West hung in the main meeting room at the new location. I asked students if they had any idea what that photograph represented. My question drew only blank stares. A history of the pioneering Southeast Asia Program at Cornell has yet to be written.

${ }^{4}$ Benedict R. O'G. Anderson, Language and Power: Exploring Political Cultures in Indonesia (Ithaca: Cornell University Press, 1990).

${ }^{5}$ See also the section entitled "Personal Vectors" in Anderson's The Specter of Comparisons: Nationalism, Southeast Asia, and the World (London: Verso Press, 1998), 18-20. 
of South Asians. A fight suddenly broke out, initiated by a group of English students hurling racial epithets at the demonstrators. Ben found himself in the middle, trying to stop the fight. "My spectacles were smacked off my face," he recounts, "and so, by chance, I joined the column of the assaulted." ${ }^{\prime}$ The rest of Ben's account consists of tracing the cracks created by such a chance encounter, cracks that lead to more fortuitous meetings and unexpected events.

His interest in Asia stoked by the violent episode, he decided to learn about Indonesia, which had been in the news. He had heard that there were only two places where Indonesia was being seriously studied: Yale and Cornell. Thanks to an "old friend," he found a teaching assistantship at Cornell, where he met his most important mentors: George Kahin, John Echols, James T. Siegel, and Claire Holt. ${ }^{7}$ Aside from Kahin and Siegel, it was Holt, an art historian, who had the most profound effect on Ben, in part because she mirrored his own predicament as an exile many times displaced and yet seemed to be at home everywhere. Ben described himself as "someone born in China, raised in three countries, speaking with an obsolete English accent, carrying an Irish passport, living in America, and devoted to Southeast Asia"; the author of an "odd book" on nationalism, Imagined Communities, "that could only be written from various exiles and with divided loyalties." ${ }^{8}$

Claire Holt was the daughter of a wealthy Jewish family from Riga, Latvia; a dancer in Paris and New York; then the lover of the Dutch scholar William Stutterheim. She had lived in colonial Java in the 1930s, worked as a translator for the US military during the war, and fled the McCarthyism of Washington to Ithaca at the invitation of Kahin, to teach courses in Indonesian culture. It was precisely her lack of formal academic training that made her so valued by her students, particularly Ben. ${ }^{9}$ Her interest in Javanese mythology, arrived at unintentionally through her wanderings and love affairs, encouraged Ben to think about Indonesian politics through the lens of its cultural logics. The result, as many of those in Southeast Asian studies know, has been a series of highly influential essays on the politics and culture of the Indonesian Revolution and its counterrevolutionary aftermath. ${ }^{10}$

One of his earliest comparative essays was his classic piece, "The Idea of Power in Javanese Culture."11 As Ben relates it, the essay owes its genesis to the simultaneous presence of two people at Cornell while he was a junior faculty member: the renowned conservative philosopher Allan Bloom and the well-known Javanese historian Soemarsaid Moertono. Neither knew the other, and it was Ben who stumbled on the connection between the two. One day, he overheard Bloom talking to another colleague about how the ancient Greek philosophers had no equivalent for the modern

\footnotetext{
${ }^{6}$ Anderson, Language and Power. 1.

7 Ibid., 9. See also Benedict Anderson, “Frameworks of Comparison," London Review of Books 38, 2 (January $21,2016), 15-18$.

${ }^{8}$ Anderson, Language and Power, 10.

${ }_{9}$ See Claire Holt, Art in Indonesia: Continuities and Change (Ithaca: Cornell University Press, 1967). For a fuller biography of Holt, see Deena Burton, Sitting at the Feet of Gurus: The Life and Dance Ethnography of Claire Holt (Bloomington, IN: Xlibris Books, 2009).

${ }^{10}$ Anderson, Language and Power, 10.

" "The Idea of Power in Javanese Culture," in Culture and Politics in Indonesia, ed. Claire Holt (Ithaca: Cornell University Press, 1972), 1-70.
} 
concept of "power." For one thing, they had no word for it that remotely approximated modern Western usage. At the same time, Ben remembered reading Moertono's master's thesis that related the story of an eighteenth-century Javanese monarch who died without leaving an heir. At his wake, one of his sons noticed that the dead king's penis was erect, a small amount of "glowing liquid" oozing from its tip. He quickly sipped this liquid, thereby absorbing "the tédja, or magic light of kingship," enabling him to assume the throne. Like the ancient Greeks, the Javanese seemed to have a notion of power that was material rather than abstract, and so thanks to the wholly contingent presence of Bloom and Moertono, Ben came to think of the comparability of Javanese and Western rationality, beginning with the difference, as well as similarities, in their ideas about power. ${ }^{12}$

Such unexpected conjunctions informed, or at least triggered, much of Ben's work. While doing fieldwork in post-revolutionary Indonesia during the early 1960s, his interests were guided by dramatic happenings. Jakarta then was adrift with possibilities, rumors, and contradictions, yet also awash in what appeared to be a genuinely egalitarian ethos. While there, he writes, he "was lucky enough to have two remarkable elderly Javanese teachers who were also brothers" to teach him about "traditional" Javanese culture while remaining "wholly sharp-eyed" about its delusions. "Luck" in this case also foreshadowed catastrophe. The coup and subsequent massacres of 1965-66, which were totally unexpected both in their extent and viciousness, led to Suharto's dictatorship and the subsequent banning of Ben from Indonesia for having coauthored a report implicating the regime for its role in the coup and the killings that followed.

But again as luck would have it, Ben's exile from Indonesia coincided with the overthrow of the military dictatorship in Thailand in 1973 and the return to a more open society. Having cultivated close friendships with a number of Thai dissident intellectuals, Ben was given another chance to pursue his interests in Southeast Asian revolutionary movements. And in an even more fortuitous spin of the wheel, his brother Perry Anderson had been editing the New Left Review and had written important comparative works on the history of nation-state formation in Europe. Thanks to the accident of birth, Ben found his intellectual and political horizons shifting again, toward more comparative directions. In the midst of his own repeated displacements and exiles, he finds himself haunted by unsettling questions about solidarity, difference, and imagination, while accompanied by a recurring object of love, the "imagined community." The latter is alternately figured as the nation and as the family in its most extended forms: mentors, colleagues, students, and friends from various parts of the world linked by the generosity and affection of their regard. ${ }^{13}$ The imagined community, born out of a series of violent mishaps and exiles, contingent meetings and ghostly questions, is also a community of sentiment.

The very title of his famous book on nationalism suggests as much. It was written in the midst of the war between two socialist countries, Vietnam and Cambodia, and in response to the debates in the UK about the break-up of Great Britain. Nationalism, like religion, had been derided as a utopian fantasy by European Marxists, and as a

12 Anderson, "Frameworks of Comparison."

${ }^{13}$ Anderson, Language and Power, 6, 14. See also the dedication in Anderson's The Spectre of Comparisons. 
useless impediment to globalization by proponents of neo-liberalism. Ben returned to the conditions of possibility that gave rise to nationalist imaginings, seeking to reconstruct what was once so compelling and persuasive about its discourse. At the same time, he was less interested in providing a general theory about nationalist formation as he was in demolishing cherished myths about the immemorial and timeless nature that nation-states ascribed to themselves. He argued that nationalism was a kind of substitute for religion. It anticipated revolution even as it sought to sublimate its destructive force. Emerging from experiences of "creole pilgrimages," "homogenous empty time," the break up of sacred communities, and the vernacularization of sacred languages thanks to the conjunction of capitalism and print, nationalism could retrospectively be reckoned as a sustained, "piratable" project for constructing community amid conditions of anonymity. Here is Ben's own selfeffacing evaluation, in 2011, of the modest goals and surprising reach of his book despite, or perhaps because of, its broad comparisons:

Fools step in where angels fear to tread. In fact, I have always been surprised how little severe criticism I ever got about [Imagined Communities]. One reason must have been the fact that I didn't concentrate on any one country or region, so the scale of the theory was super-macro. Basically it was also very simple: technology + capitalism + Tower of Babel $=$ nationalism! Hahahaha! ${ }^{14}$

This brings us to the other key feature of Ben's work: comparison. For Ben, comparison was less a methodology than what he called a "discursive strategy." 15 It entailed developing a keen awareness of "strangeness and absence," thereby opening oneself up to what he called, borrowing from José Rizal, the "specter, or devil, of comparison." The effectiveness of comparisons could be gauged by the "surprise" they produced-or what Ben might call shock effects, catching readers "off guard" by their unexpected juxtapositions among different sites or longitudinal arc within the same site. ${ }^{16}$ How did this discourse of comparison prove so generative? Here's an example: Ben's opening paragraphs to his review of Soledad Locsin's translation of José Rizal's Noli Me Tangere:

Few countries give the observer a deeper feeling of historical vertigo than the Philippines. Seen from Asia, the armed uprising against Spanish rule of 1896, which triumphed temporarily with the establishment of an independent republic in 1898, makes it the visionary forerunner of all the other anti-colonial movements in the region. Seen from Latin America, it is, with Cuba, the last of the Spanish imperial possessions to have thrown off the yoke, seventy-five years after the rest. Profoundly marked, after three and a half centuries of Spanish rule, by Counter-Reformation Catholicism, it was the only colony in the Empire where the Spanish language never became widely understood. But it was also the only colony in Asia to have had a university in the nineteenth century. In the 1890 s barely 3 percent of the population knew "Castilian," but it was Spanish readers and writers who managed to turn movements of resistance to colonial rule from hopeless peasant uprisings into a revolution. Today, thanks to

${ }^{14}$ Benedict Anderson, "Interview: Comparatively Speaking: On Area Studies, Theory, and 'Gentlemanly Polemics," Philippine Studies 59, 1 (2011): 127.

${ }^{15}$ See Anderson, "Frameworks of Comparison," 16.

16 Ibid., 17-18. 
American imperialism, and the Philippines' new self-identification as "Asian," almost no one other than a few scholars understands the language in which the revolutionary heroes communicated among themselves and with the outside world-to say nothing of the written archive of pre-twentieth-century Philippine history. A virtual lobotomy has taken place.

The central figure in the revolutionary generation was José Rizal, poet, novelist, ophthalmologist, historian, doctor, polemical essayist, moralist, and political dreamer. He was born in 1861 into a well-to-do family of mixed Chinese, Japanese, Spanish, Tagalog descent: five years after Freud, four years after Conrad, one year after Chekhov; the same year as Tagore; five years before Sun Yat-sen, three years before Max Weber, eight years before Gandhi, and nine before Lenin. Thirty-five years later he was arrested on false charges of inciting Andrés Bonifacio's uprising of August 1896, and executed by a firing squad composed of native soldiers led by Spanish officers. The execution was carried out in what is now the beautiful Luneta Park, which fronts the shoreline of Manila Bay. (On the other side of the Spanish world, José Martí, the hero of Cuban nationalism, had died in action the previous year.) At the time of Rizal's death, Lenin had just been sentenced to exile in Siberia, Sun Yat-sen had begun organising for Chinese nationalism outside China, and Gandhi was conducting his early experiments in anti-colonial resistance in South Africa. ${ }^{17}$

Comparison in Ben's hands was meant to provoke the rethinking of received ideas beyond accepted boundaries. In the passage above, we see how he reintroduces the Philippines to the metropolitan readers of the London Review of Books, then later to middle-class Filipinos and other Southeast Asians, by repositioning it in terms of vast world historical forces. The sense of vertigo he invokes arises from grasping the country's history emerging from the great historical tides washing over one corner of the globe to the other. Unexpected chain reactions result in unforeseen cascades of change that resonate and reverberate through the archipelago, rippling in turn to other parts of the world. History emerges here as a phantasmagoria of possibilitiesinflecting, decentering, and displacing one another. Reading Ben, one begins to feel the Philippines as a tenuous collection of sites ready to come apart and come together in new ways.

Similarly, he introduces Rizal as a world historical figure: not the privileged boy from Calamba destined for greatness, but as a repository for an interminably hybrid history, kin to those other great modernists of the world: Freud, Conrad, Chekov, Sun-Yat Sen, Tagore, and Lenin among others. In this way, Ben maps Rizal's life within the shifting force fields of the revolutionary nineteenth century. By deprovincializing Rizal, he recasts him into a cosmopolitan figure whose writings and legacy belong not so much to one country or one people. Rather, they become part of the common inheritance of the rest of humanity.

This, in my opinion, is the basis for Ben's genius. By pursuing such comparisonsor better yet, opening himself to being possessed by their unexpected ghosts-he leads us to see what is often so obvious and, for that reason, remains invisible in front of our own eyes. His greatness as a scholar and as a teacher lay in his ability to poke

${ }_{17}$ Benedict Anderson, "First Filipino," London Review of Books 19, 20 (October 16, 1997), 22. 
and probe underneath layers of mystifications and the garbage of half-truths covered over by the habits of intellectual laziness and moral cowardice. At the same time, he was always alert to other possibilities that come through the inverted telescopes of time, seeing the distant connections waiting to be made: Rizal with Multatuli, Isabelo de los Reyes with Malatesta, Sukarno with Hitler, for example. Out of these surprising and contingent relays of rumors, gossip, jokes, novels, poems, testimonies, newspaper articles, government reports, census surveys-these massive and promiscuous mixing of texts and tales, works and lives-Ben led us, cajoled us, prompted and forced us to see the world differently; to imagine the history of futures yet to come.

His recent death in Surabaya, Indonesia, continues to be deeply mourned by untold others. As his close friend James Siegel wrote: "An obituary conventionally names the deceased's 'contributions' as if they have been laid to rest, to be revived when necessary. Careful readers of Anderson's works will find themselves revived, living members of an organization without a form, joined in unimagined solidarity with others unknown to themselves."18

${ }^{18}$ James T. Siegel, "A Necrology of Ben Anderson," Jakarta Post, December 19, 2015, available at http://www.thejakartapost.com/news/2015/12/19/a-necrology-ben-anderson.html, accessed May 18, 2016. Also see Siegel's tribute to Ben in this issue of Indonesia. 